\title{
Divine Justice in Greek Mythology
}

\section{Marwa Farouk Hafez}

Lecturer at the Faculty of Tourism and Hotels, Sadat City University

\section{Abstract}

This research discusses the concept of divine justice in Greek mythology and traces its roots in the ancient Egyptian believes. The concept of the divine juistice could be identified as the punishment of the deities to the mortals or immortals because of their sins. The Greeks had a goddess of divine retribution, who was

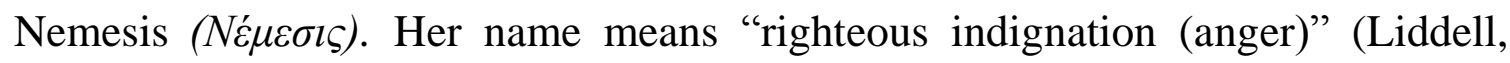
Scott, 1968), which was directed to those who have broken the law of nature. She was a personification of an abstract concept, which was divine retribution (Daly , 2004). She was represented with wings particularly in her later images (Kerényi, 1974). Nemesis was believed to reward virtues and to punish sins. She represented the wrath of the deities (Daly, 2004). Actually, the personification of abstract ideas, in general, and the personification of justice in particular, most probably came from Egypt. The personification of truth, justice, and cosmic order was goddess Maat according to the ancient Egyptian believes (Wilkinson, 2003).

Keywords: Divine justice, Greek mythology, Ancient Egyptian.

\section{Introduction}

Goddess Maat played a very important role throughout the ancient Egyptian history. The name of goddess Maat means truth, justice, cosmic order, right, and real actions according to Rainer Hannig. Gardiner suggested that the word Maat also signified "that which is straight or direct". Moreover, this meaning could be defined by the Latin word "rectum"(Sabra, 2003). Goddess Maat was deeply rooted in the ancient Egyptian mythology as she appeared as early as the Old Kingdom. The Pyramid Texts stated that she was believed to stand behind the Sun-god Re. Maat was referred to as "the daughter of Re" in the New Kingdom. She also became associated with Osiris as he was called "the lord of Maat". The goddess was thought to be the consort of Thoth. The great significance of Maat is reflected in her titles "the foods of the gods", "the breath", and "the clothing" as the deities were believed to "live on Maat" (Wilkinson, 2003).

Divine justice in Egyptian mythology was well-represented in the myth of the struggle between Horus and Seth. Justice was established in this myth and Horus held the office of his father Osiris, who in his turn became the god of the Dead. Whereas, Seth was recompensed by becoming the Son and assistant of the Sungod Re. 
This was probably done to point out that the role of kingship was making peace and solving any possible conflict. It is also manifested in the daily struggle of Re and Apophis, the evil serpent ending with the victory of justice upon evil forces. Moreover, divine retribution is emphasized in the myth of the blinding of Truth and Falsehood. This myth dates back to the New Kingdom and tells that Truth and Falsehood were two brothers. Truth was wrongly accused by his brother falsehood of not returning his precious dagger that was borrowed by Truth. The Ennead punished Truth by blinding him and he was forced to work as the doorkeeper of the falsehood (Sabra, 2003).

Then, Truth managed to flee and a fair lady had an affair with him. She gave birth to a son and made Truth the doorkeeper of her house. This son did not know that the blind doorkeeper was in fact his father until he grew up. Finally, he succeeded to prove the innocence of his father to the Ennead. Falsehood was punished by blinding both eyes. Furthermore, he was tortured with five open wounds. The last punishment was sentenced to criminal in the Ramesside Period. The woman retribution was declared by her son that she deserved that her family would be assembled and a crocodile would be summoned. In other words, her sentence should be put to death. Divine justice appeared in the story of the two brothers of Anubis and Bata. Anubis murdered his wife because she wanted to betray him with his brother Bata. In spite of not doing the real sin of adultery, the wife was murdered because she claimed falsely that the younger brother was the sinner. Even Bata who became the king had a wicked woman whom he had her been trialed and consequently justice had been administered (Sabra, 2003). The married women, who committed the sin of adultery, were stoned to death in Islam.

The most famous instances of divine punishments in Greek mythology were those of Atlas, Prometheus, Medusa, Andromeda, Cassandra and Laocoon. Atlas (A $\tau \lambda \alpha \varsigma)$ (Grimal, 1990), (pl.1) whose name means "the very enduring" (March, 1998), was a giant and a Titan. He was the son of Iapetus and an Oceanid Clymene or perhaps Asia. Other traditions mentioned that Atlas was the son of Uranus, and consequently a brother of Cronus. He was from generation of monsters that came before the Olympian deities (Grimal, 1990). Atlas led the Titans in their war against the Olympian deities. When the Olympians won the war, they punished Atlas of carrying the sky on his shoulder for all eternity (March, 1998). 
While Heracles was fulfilling one of his legendary twelve labours, he carried the sky instead of Atlas (Daly, 2004). This was the eleventh labour, which was to bring the golden apples of the Hesperides for Eurystheus. The giant brought back the golden apples to the hero-god Heracles and intended not retrieve his burden again. However, Heracles was able to trick him by asking for a moment so that he might put a padded cushion on his head or shoulders (March, 1998).

The Hero Perseus, who was another son of Zeus, turned Atlas into stone using the head of the Medusa after slaying this monster according to the Ovid's Metamorphoses (Riley, 1858). Therefore, Atlas became a mountain range in the northwest of Africa (Grimal, 1990).

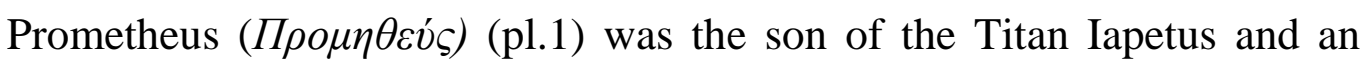
Oceanid Clymene or Asia (Grimal, 1990). His name means "forethought". Therefore, Prometheus was also a Titan, who was the brother of Epimetheus (Afterthought), Atlas and Menoetius. Prometheus fashioned the humans of clay by the orders of Zeus according to the Greek myth. Prometheus gave those mortals the gift of fire without the permission of the deities. He was regarded by the Greeks as the Champion and benefactor of mankind. He tricked Zeus and caused that the poorer parts of the sacrifices being offered to the gods, while the better parts being eaten by humans. Prometheus gave those mortals the gift of fire without the permission of Zeus. Consequently, he brought for himself and the humankind the divine retribution of Zeus (March, 1998).

Zeus sent Pandora (П $\Pi v \delta \dot{\omega} \rho \alpha)$ or (the all-endowed) (Liddell, Scott, 1846), who was the first woman on earth. In other words, she was Eve of the Greek mythology (Dixon- Kennedy, 1998). Zeus order Hephaestus to fashion her and all the deities bestowed upon her gifts. She was charming, beautiful but in the same time very cunning. They gave her a sacred vase or a box and ordered her not to open it (Daly, 2004).

Prometheus warned his brother Epimetheus not to accept any present from Zeus (Houle, 2001). However, he could not resist Pandora and then he married her. She could not prevent herself from opening the box, and when she it all evils and miseries came out from it. Only hope remained in the vase or the box and by hope only human might overcome all sufferings (Daly, 2004). Pandora has a strong similarity to Eve in Christianity in the way she encouraged Adam to eat the forbidden fruit and consequently both were expelled from Heaven. Moreover, in the Western culture, there is a famous French proverb s saying "chercher la femme." Nevertheless, it was the fault of both Adam and Eve for obeying the devil 
Afterwards, Prometheus was punished by Zeus, therefore, he was chained to a rock on the Caucasus Mountains and a great eagle came to eat his liver every day, whereas it grew back at night (Grimal, 1990). Modern Science proved that the liver is only organ that could renew itself. Finally, Prometheus was freed by Heracles, who shot and killed the eagle. Prometheus had the gift of foreseeing (Houle, 2001), and he told Heracles that Atlas was the only one who could bring him the golden apples of the Hesperides (March, 1998). This punishment seems to be extremely cruel for the modern mind. However, it is similar to crucifixion in the ancient world and also in Christianity.

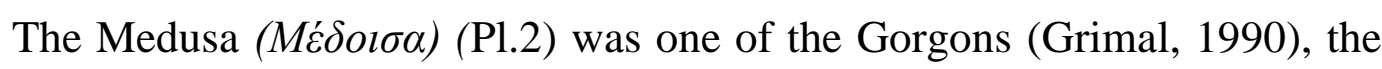
grim ones (Daly, 2004). Originally, they were three pretty daughters of the Titans Phorcys and Ceto, who were sea gods. These maidens were called Stheno, Euryale, and Medusa. Stheno and Euryale were immortals, while Medusa was mortals. She slept with Poseidon, the sea deity, in a temple sacred to Athena. She was turned into a monster by Athena as well as her sisters. They had golden wings, claws of bronze and broad mouths with tusks (Dixon-Kennedy, 1998). Their necks were covered with dragon's scales. Their hair-locks were snakes. Their eyes were believed to turn any humans into stones. However, this punishment was not enough for goddess Athena. She helped hero Perseus (Grimal, 1990), who was the son of Zeus and Danae (Homer, Merrril (trans.), 2007), the daughter of the king of Argos, to behead the Medusa, whereas she protected him with her shield (Grimal, 1990).

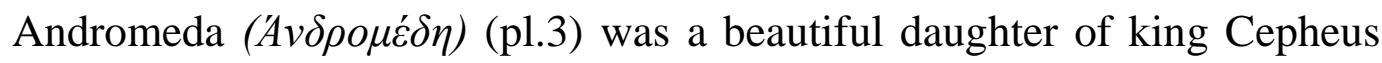
of Ethiopia and his consort Cassiopia. Cassiopia said that her daughter (or) surpassed in beauty all the Nereids all together. Therefore, the Nereids, who were the daughters of Poseidon, complained this insult to their father. Poseidon ordered the sea monster Cetus to destroy Ethiopia, which was a country on the northeast of Africa (Grimal, 1990). The oracle of Ammon said that the country could be saved if Andromeda sacrificed to Cetus (Dixon- Kennedy, 1998) Eventually, she was chained to a rock on a cliff on the sea. Meanwhile, Perseus saw the beautiful young girl, while he was returning from his the journey of slaying the Gorgon (Medusa). He felled in her love from the first sight. Pereus offered her parents that he would save her if they approved his marriage to their daughter. They agreed to his request, afterwards, he got rid of Cetus by lifting the head of the Medusa to him and the monster was turned into a stone. The brother of king Cepheus named Phinus was engaged to Andromeda. 
Therefore, he tried together with his followers to kidnap the pride on the wedding day, but Perseus got rid of him and his followers by using the head of the Medusa and then they were turned into stones (Grimal, 1990). Later on, Andromeda, Cassiopia and even Cetus were honoured by calling constellations of stars after them (Daly, 2004). This sentence to be offered to the monsters occurred in the Roman period, when criminals and later on Christians were offered to wild animals such as lions and tigers.

Cassandra $(K \alpha \sigma \sigma \alpha \dot{v} \delta \rho \alpha)$ was the daughter of King Priam of Troy. She was granted the gift of prophecy by Apollo, who loved her. She rejected his love, therefore, her retribution was that her prophecies would never been believed

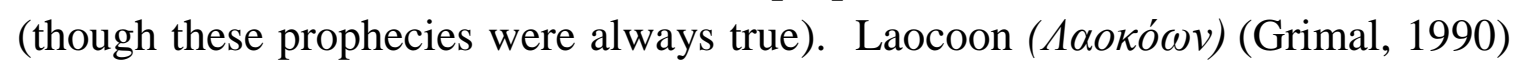
(pl.4) was a Trajan priest of Apollo and Poseidon. He was also the son of Antenor of Troy. He broke his vow of celibacy. He got married and gave birth to sons. The deities sent him giant serpents that killed him together with his sons (DixonKennedy, 1998). Priests in Ancient Greece were not permitted to be married as in the case of monks in Christianity.

Nemesis (NÉ $\mu \varepsilon \sigma \iota \varsigma)$ was both the goddess and personification of the abstract concept of divine justice or retribution (Grimal, 1990). She was the daughter of Oceanos (Daly, 2004), and Night (Nyx) (Athanassankis, 2004). Her name means righteous anger (Liddell, Scott,1846) or righteous indignation, which was directed to those who have broken the laws of nature. She was represented with wings particularly in her later images (Kerényi, 1974). Nemesis was believed to reward virtues and to punish sins. She represented the wrath of the deities. Moreover, Nemesis was thought to punish those who had hubris, which was a Greek word (Daly, 2004) meaning excess (of pride, wealth, or even good fortune). Croesus was a very wealthy and powerful man. He was charmed by Nemesis to carry out an expedition against Cyrosus that led him to his death (Grimal, 1990).

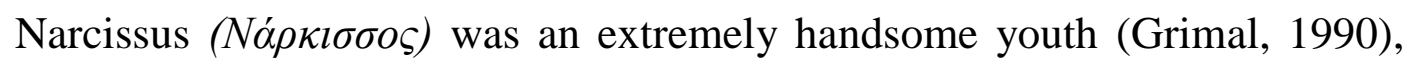
who was the son of the River Cephisus and the nymph Liriope (Dixon- Kennedy, 1998). He was too proud of himself, thus, he rejected the love of many nymphs, who prayed to Nemesis avenge him. He was cursed by Nemesis to fall in love with his own reflection on the river Styx. He started to gaze and stare at his reflection until he got mad and fell down in the water. Then, a flower, which was named after him, came out from the place of his fall (Grimal, 1990). The myth of Narcissus has its impact on modern times as in psychology there is a complex called Narcissism. One is a Narcissist if he loves extremely himself only. Furthermore, if one stares in the mirror for a long time, he could be mad according to Egyptian superstition as Narcissus did may be because of demons or genii. 


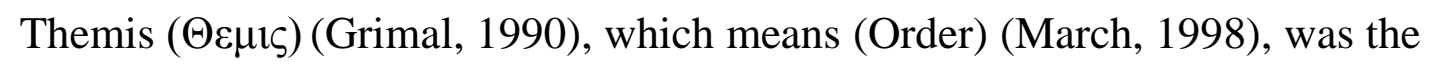
Greek goddess of Law and Order (Grimal, 1990). She was a Titan, who was the daughter of Uranus (Heaven) and Gaia (Earth). Themis had daughters from Zeus, who were the three Horae (Seasons) and the three Fates. These daughters represented forms of order in the universe. Zeus and Themis planned the Trojan War in order to overcome the overpopulation of the earth (March, 1998). She was represented as a woman with a band around her eyes holding a pair of scales symbolizing justice. Her insignia was also taken by her daughter Astraea. This daughter was also regarded as personification of justice by the Greeks (DixonKennedy, 1998). On the modern courts, justice is represented as a blind woman carrying the scales.

Finally, Maat was like Nemesis a goddess and a personification of abstract idea. They were represented as a winged woman. Nemesis was represented retribution, while Maat and Themis represented Law and Order. Maat was present in the Final Judgment and the heart of the dead was scaled against her feather. The one who executed the retribution was the monster amam the devourer or the one who devour the heart of the sinful persons, whereas Andromeda was presented to the monster Cetus because of her mother fault. Maat had a significant role on the afterlife, whereas Nemesis did not possess such role. Maat represented the Latin word rectum or straight, while Nemesis was believed to cut off the Latin word hubris. In other words, Nemesis cut off undeserved gifts from mortals. The Laocoon was punished together with all his children, despite the guilt was merely his. However, the guilty person was only punished in the Egyptian Mythology.

The concept of divine justice played a very important role in both the Egyptian and Greek mythologies. Disobeying, tricking the deities (Cassandra), and violation of the temples (the Medusa), and breaking the vows of celibacy for the priests (Laocoon) and even nymph, all required divine retribution according to Greek beliefs. The punishments in Greek mythology were eternal labor, torturing, and turning into a monster or even presented to monsters. Furthermore, other punishments were sending monsters to devour the wrongdoings, madness, as well as putting into death. Punishments in the Egyptian Mythology were blinding as in the case of the Falsehood, opening wounds, offering to a crocodile as in the story of the two brothers and execution. 


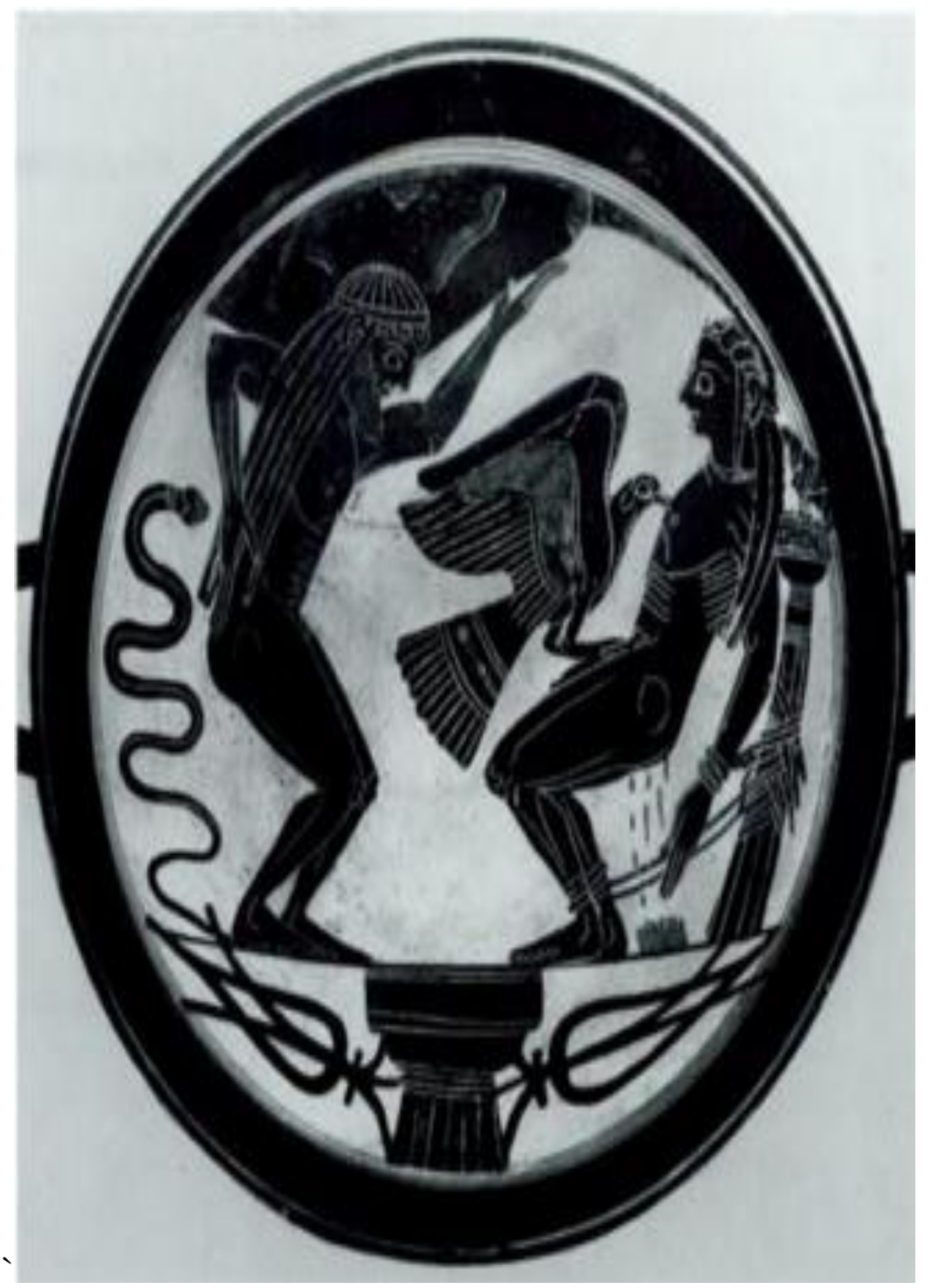

Pl. (1) The Punishment of Atlas and Prometheus, Laconian cup by the Arkselias painter, c. 550 BC, The Vatican, 16592.

After (Grifithes, (trans), Schefold, 1993) pl. 56 


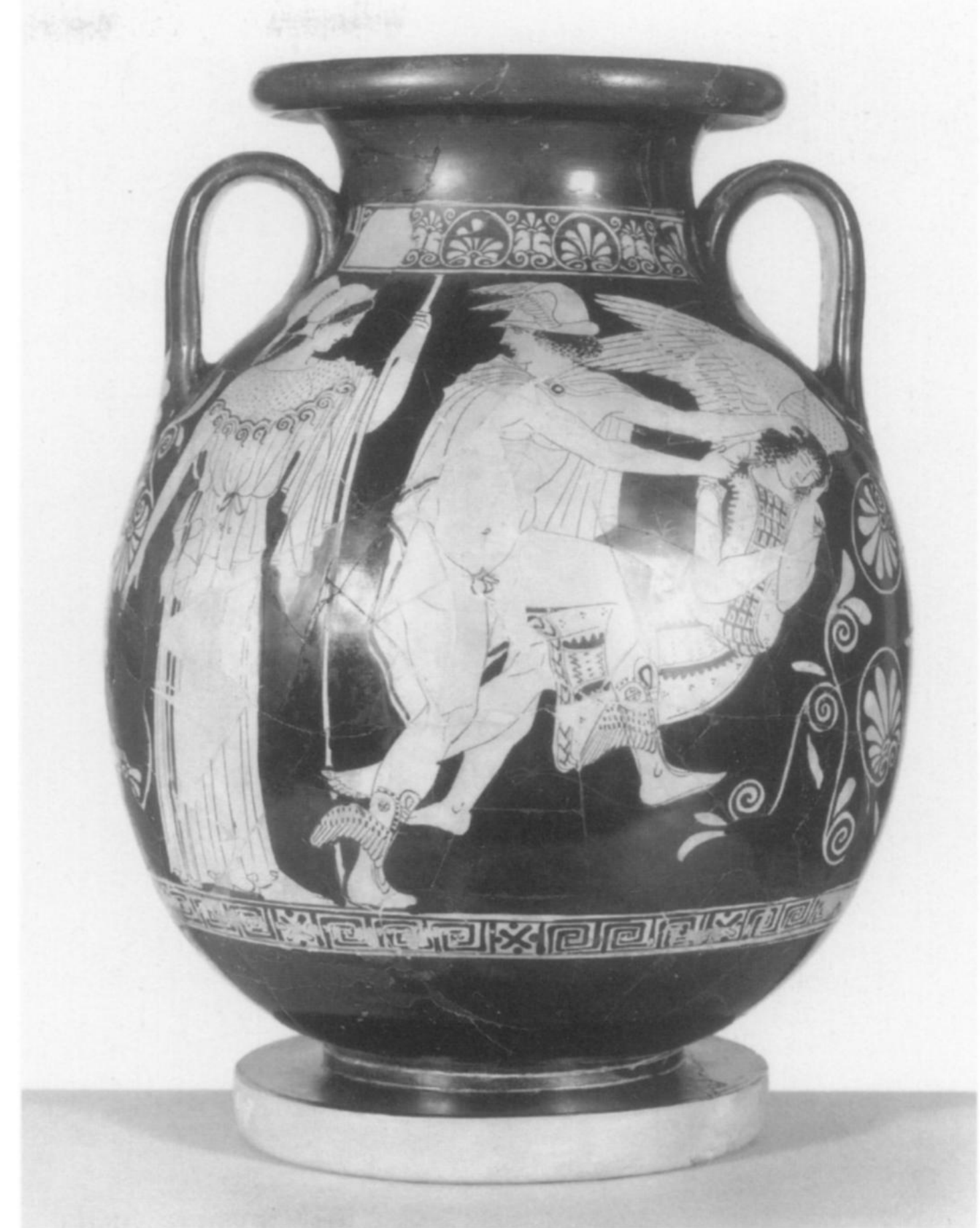

Pl. (2) Perseus beheading the Gorgon Medusa, Attic red-figure, pelike, ca.450-440 BC, Polygnotos, NewYork Metropolitan Museum of Art, Roger Fund 1945 (45.11.1)

After (Topper, 2007). Fig. 2 


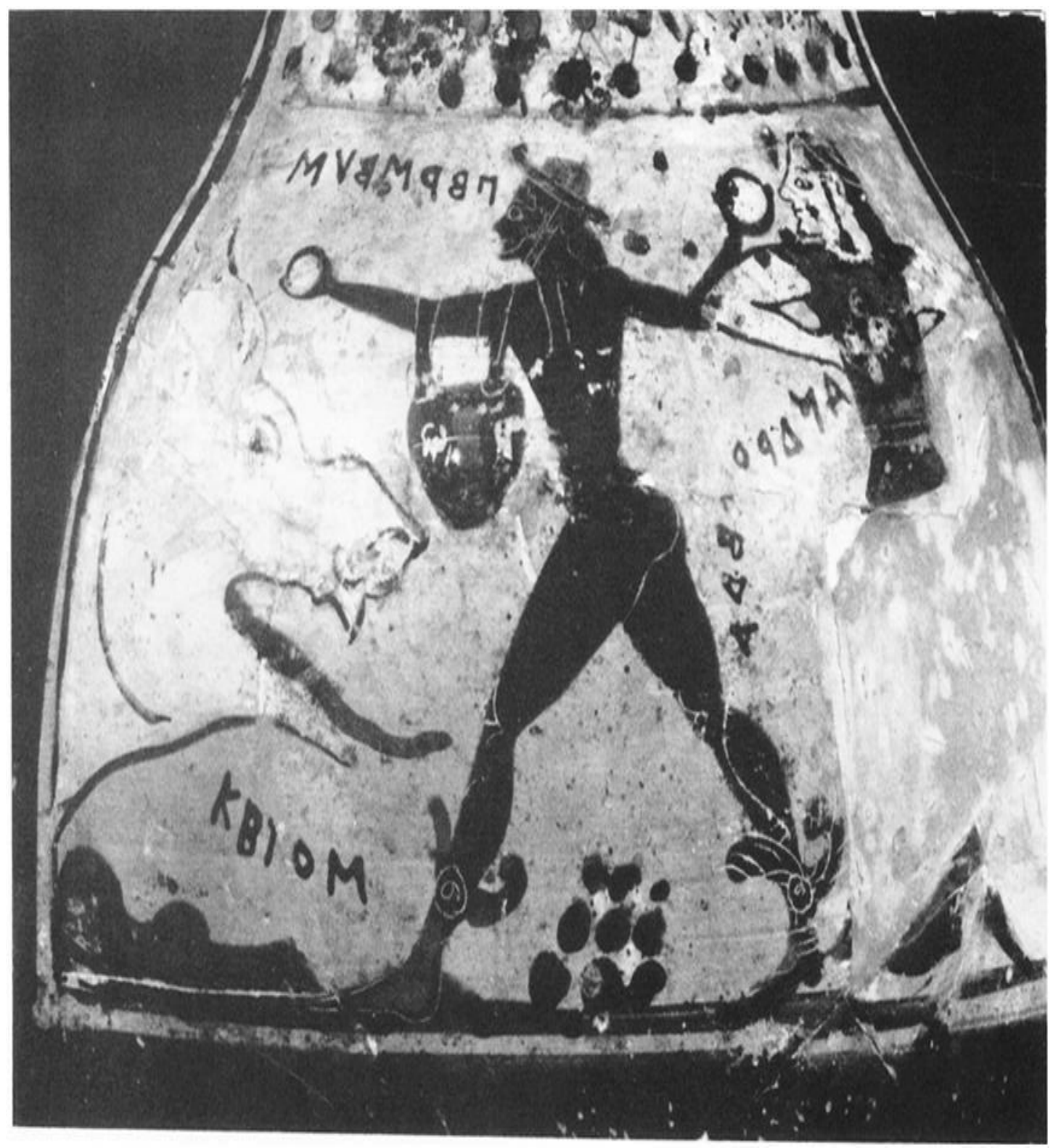

Pl.3- Late Corinthian amphora, Berlin, Staatliche Museen F. 1625 (Courtesy Museum), Sixth century BC. It depicts Perseus, Andromeda, and Cetus. After (Phillips,1968) Plate1, Fig.1 


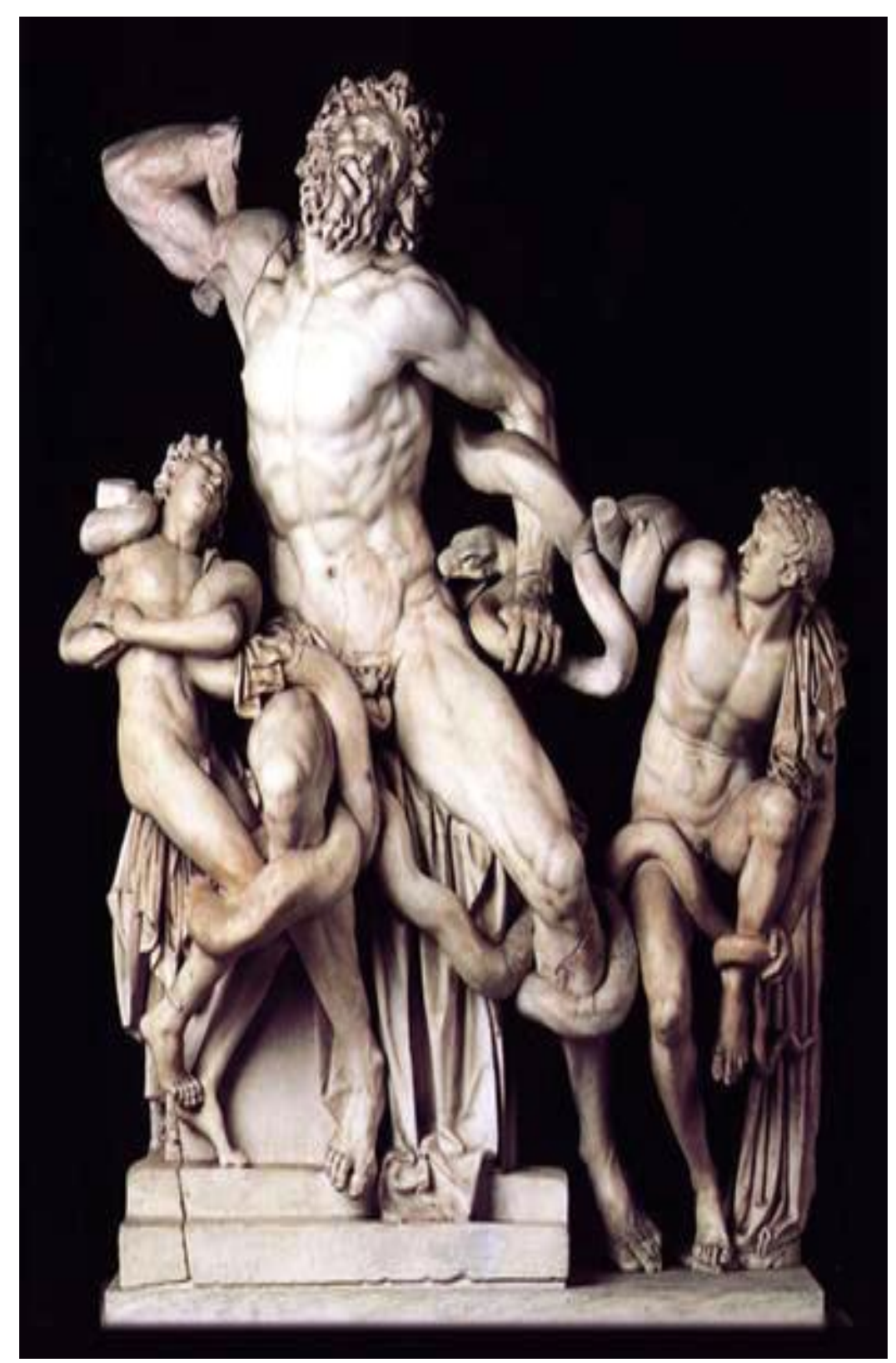

(P1.4) The Laocoon Group, first century B.C, marble, $2.1 \mathrm{~m} \mathrm{H}$, Vatican Museums, Rome. A Roman copy after a Greek original of the fifth century BC. After (Janson H. \&Janson, A., 2004) 


\section{Reference}

Athanassankis, A. (2004), Hesiod, Works, Days, and Shield (2nd ed.), London., p. 42.

Daly, N. (2004), Greek and Roman Mythology A to Z, New York. p. 10, 19, 20, $55,89,99$.

Dixon- Kennedy, M. (1998), Encyclopedia of Greco-Roman Mythology, Santa Barbra,.p. 32, 140, 186,187, 215, 296,.

Grifithes, A., (trans), Schefold, K., (aut). (1993). Gods and Heroes in Late Archaic Greek Art. London, p. 53.

Grimal, P. (1990), The Concise Dictionary of Classical Mythology, Oxford, p. 43, 44, 68, , 86, 164, 261, 286, 289, 376, 427.

Homer, Merrril, R. (trans), (2007), The Illiad, Michigan, p. 459

Houle, M. (2001). Gods and Goddesses in Greek Mythology. New Jersey, pp. 40$50,55$.

Janson H. \&Janson, A. (2004). History of Art, the Western Tradition. New Jersey, vol.1, p. 162.

Kerényi, K. (1974). The gods of the Greeks, Edinbirgh,p. 144.

Liddell, H, Scott, R. (1846), A Greek-English Lexicon, New York, p. 962, 963, 1091.

March, J. (1998), Cassel's Dictionary of Classical Mythology, London, p. 153, $154,664,665,739$.

Phillips, K. (1968). Perseus and Andomeda. American Journal of Archaeology, 72, NO. 1, p.24.

Riley, H. (1858, The Metamphorses of Ovid, London, p. ix.

Sabra, A. (2003). Social Justice in Ancient Egyp,unpublished thesis, Alexandria, pp. 23, 131- 173.

Topper, k. (2007). Perseus, the Maiden Meusa and the Imagery of Abduction. Hesperia : Journal of American School of Classical Studies at Athens, 76, No.1, pp.73-105.

Wilkinson, R. (2003), The Complete Gods and Goddesses of Ancient Egypt, London, pp. 15o- 152. 


\section{العدالة الإلهية في الأساطير اليونانية}

$$
\text { ملخص عربى }
$$

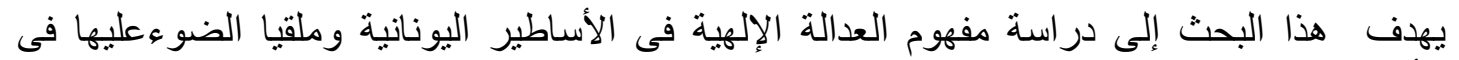

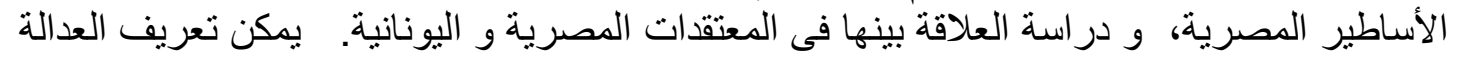

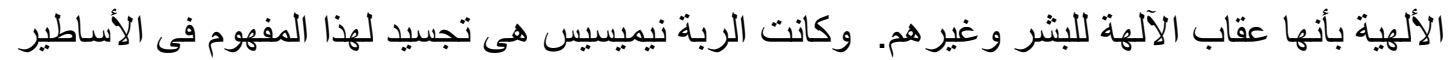

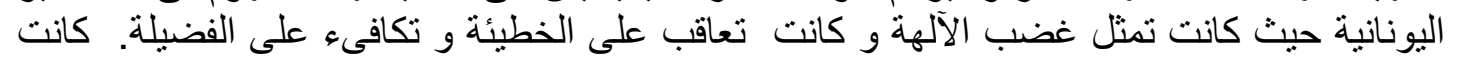

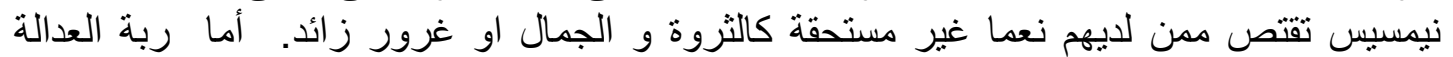

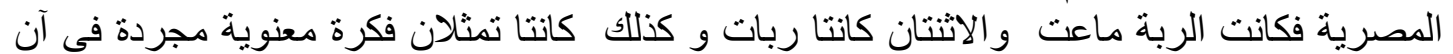

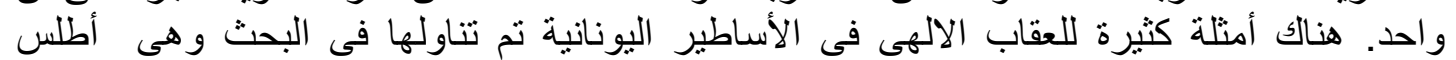

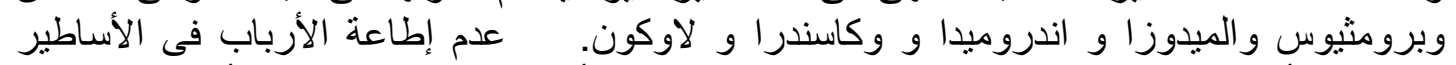

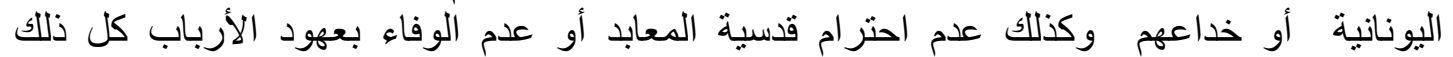
يستوجب العقاب. كان العقاب عل تلك الخطايا يكون بالقتل أو العذاب الأبدى أو أو الجنون أو أو بالتحويل إلى وحوش أو بالتقديم كوليمة للوحوش البقاب عل الول 